\title{
The complementarity norm: service provision by the welfare state and voluntary organisations in Sweden
}

\author{
Lena Dahlberg PhD
}

Centre for Research and Evaluation, Sheffield Hallam University, Sheffield, UK

\author{
Correspondence \\ Lena Dahlberg PhD \\ Centre for Research and Evaluation \\ Sheffield Hallam University \\ Church House \\ City Campus \\ Howard Street \\ Sheffield S1 1WB \\ UK \\ E-mail: L.Dahlberg@shu.ac.uk
}

\begin{abstract}
Previous research has shown that different providers of social welfare tend to provide complementary services at a local level, but that there is no complete task specialisation. This means that elements of complementarity theory are challenged, especially the so-called 'principle of matching', i.e. that actors only undertake tasks which match their characteristics. The aim of the present study was to explore complementarity between Swedish local authorities and voluntary organisations in their support for relatives of older people. Interviews were carried out with 55 politicians, civil servants and representatives of voluntary organisations drawn from four municipalities. These municipalities were selected from a sampling frame that ensured representation of different combinations of high and low levels of voluntary and statutory services. Qualitative analysis of interview transcripts showed that, while local authorities are seen as responsible for the support for relatives, voluntary organisations are expected to be complementary, offering 'the icing on the cake', i.e. social support and activities which are regarded as less demanding. Overall, substantial support for a norm of complementarity was found. It is argued that, if those who are active in social policy and voluntary work at a local level agree with the ideal of complementarity, this will influence their wish to arrange activities and services. Therefore, the complementarity norm - rather than the principle of matching - influences the outcome in terms of service provision.
\end{abstract}

Keywords: complementarity, informal care, older people, Sweden, voluntary organisation, welfare state

Accepted for publication 21 December 2005

\section{Introduction}

Ageing populations and an increasing demand for health and social services in Western countries (Kinsella \& Velkoff 2002, European Commission 2004) have lead to a an intensified social debate (Esping-Andersen 2002). Different models of social welfare arrangements have been identified; for instance, in Esping-Andersen's (1990) welfare regime approach. His work recognised that state responsibility for the care of older people is most pronounced in social-democratic welfare regimes such as the Nordic countries, and it has been argued that, in such regimes, 'the room left for service-providing nonprofit organisations [is] quite constrained' (Anheier \&
Salamon 2001, p. 15). By comparison, voluntary organisations and the market are supposed to play an important role in so-called liberal regimes, such as the USA, Canada, Australia and the UK, whereas the state is assumed to have made common cause with voluntary organisations in so-called corporatist regimes such as Germany (Anheier \& Salamon 2001).

However, welfare regime models are unlikely to recognise the less-dominant features of welfare arrangements and transitions within welfare regimes; for instance, in the social-democratic welfare regimes. In some of the Nordic countries, there have been significant cutbacks in service provision for, amongst others, older people, resulting in increasing differences between these countries 
(Szebehely 2005). There has also been a growing acknowledgement of the substantial contribution of informal caregivers and the importance of supporting them (Philp 2001, Socialstyrelsen 2002a), and an ideological shift towards private and voluntary alternatives to statutory services (Blomqvist 2004, Engström 2004, Henriksen \& Bundesen 2004, Jeppsson-Grassman 2005). This development is part of an international trend in which the ideology of the welfare state is replaced by an ideology of a welfare society (Giddens 1998).

Thus, even countries identified as good examples of the ideal type of welfare regime can display variations and undergo transitions. In addition to differences across countries within the same welfare regime, there are similarities between countries which are seen as representatives of different kinds of welfare models and hybrid countries which combine features from different kinds of welfare regimes (e.g. Blackman 2000, Kuhnle \& Alestalo 2000, Arts \& Gelissen 2002).

\section{Complementarity theory}

The roles of the welfare state and other service providers are further brought to light in complementarity theory (Litwak 1985), which is sometimes called specialization theory (Lingsom 1997, Daatland \& Herlofson 2001) or the task-specific model (Lyons et al. 2000). Its main assumption is that different actors provide different services. Each organisation or group has specific characteristics, which make it suitable to carry out certain tasks - the so-called 'principle of matching' (Litwak 1985, p. 27).

Formal, statutory organisations are most appropriate to complete uniform tasks which benefit from task simplification through division of labour (Litwak 1985, see also Lyons et al. 2000). Volunteers, on the other hand, are motivated by altruistic incentives and they have very limited time commitments (Litwak 1985). As a result, volunteers cannot guarantee that they will fulfil a service over a long period or for any given week. This implies that volunteers are best suited to carry out a service that can be delivered independently of whether it is going to be delivered a second time.

Litwak's (1985) theoretical development is based on care for older people. However, although he included various kinds of welfare providers in complementarity theory, in large contributions from voluntary organisations and private companies have been overlooked. Instead, complementarity theory has usually been tested only with respect to formal and informal caregivers. In doing so, several studies (e.g. Daatland 1990, Thoraeus Olsson 1990, Lingsom 1997, Attias-Donfut 2001, Schneider et al. 2003, see also Lyons \& Zarit 1999, Penning 2002) have found evidence supporting this theory. Still, it has been noted that there is almost never a complete division of labour between formal and informal caregivers (e.g. Chappell \& Blandford 1991), i.e. they are not as specialised in terms of which tasks they undertake as is assumed by complementary theory.

Likewise, there is no clear-cut division between the kinds of services provided by the welfare state and voluntary organisations (e.g. in supporting relatives of older people), and voluntary organisations sometimes undertake long-term responsibilities (Dahlberg 2003, 2004, 2005, Jegermalm 2003). Overlapping statutory and voluntary service provision is not in accordance with the assumptions of complementarity theory, and suggests that different actors do not only carry out tasks which match their characteristics.

Still, it has been shown that Swedish local authorities and voluntary organisations usually do not provide the same kind of services in the same local area (Dahlberg 2005), and that Scandinavian local authorities provide the most resource-demanding services, suggesting that voluntary organisations are complementary to statutory bodies rather than vice versa (Henriksen \& Bundesen 2004, Dahlberg 2005).

\section{The need for theoretical development}

In other words, the characteristics of the actors cannot fully explain any existent complementarity in service provision. This challenge to complementarity theory and its 'principle of matching' means that there is a need for theoretical development. The present paper considers how complementarity at a local level can be understood.

Research into complementarity theory is often carried out at an aggregated level and rarely takes more than one or a few explanatory factors into account. Voluntary organisations are mainly seen as service providers, and their actions are related to a welfare state agenda (Wijkström \& Lundström 2002, Lundström \& Svedberg 2003), which means that these organisations are not seen as proactive and influential, and that their own initiatives are not fully acknowledged (Amnå 1995).

By contrast, a contextual, bottom-up approach would highlight the ideas, norms and views of individual actors. It has been shown previously that social norms are important motives for family members to support older relatives (Winqvist 1999). It has also been argued that attitudes to the respective roles of the state and the family are 'the most significant factor[s] in understanding approaches to the care of older people across Europe' (Blackman 2000, p. 186, see also Bettio \& Plantenga 2004, Pfau-Effinger 2005).

In the present paper, interaction between local authorities and voluntary organisations with regard to service provision is explored. By focusing on the actors' 
own views, this paper will contribute to our understanding of such interaction processes and discuss the implications for complementary theory.

\section{Subjects and methods}

\section{Study setting}

The present study concerns support for relatives of older people in Sweden. Since 1998, the Swedish Social Service Act has included a recommendation that local authorities ought to support relatives caring for older people. During 1999-2001, the central state invested 300 million Swedish Kronor (about $£ 22$ million) in the development of support for relatives. Local authorities had to fulfil two conditions to get 'their' share of the state subsidy: to prepare a plan for how to develop support for relatives; and to cooperate with voluntary organisations in the development of support for relatives (Socialstyrelsen 2002a).

The present study was conducted in 2001, i.e. in the middle of a period when support for relatives in Sweden underwent great development (Socialstyrelsen 2002a, Dahlberg 2003). Therefore, it could be expected that representatives of both local authorities and voluntary organisations were reflecting on their roles at the time of the data collection.

\section{Sampling frame}

The present study was carried out by means of interviews with representatives of local authorities and voluntary organisations. In order to achieve a sample reflecting a great variation of circumstances, four municipalities (Båstad, Grums, Sandviken and Skellefteå) with varying levels of statutory and voluntary services (found in an initial survey presented in Dahlberg 2003,2004) were selected for in-depth studies. In one of these areas, both voluntary organisations and the local authority provided substantial support for relatives, while in another, both the voluntary organisations and the local authority provided limited support. In a third municipality, the voluntary support was substantial, but the local authority provided a limited support. In the final municipality, the voluntary support was limited, while the local authority provided a great amount of support.

\section{Participants}

Between 10 and 12 interviews were carried out in each municipality, making a total of 43 interviews incorporating 55 representatives of local authorities and voluntary organisations (see Table 1). In each municipality, interviews were conducted with the president of the
Table 1 Interviews with local authorities and voluntary organisations

\begin{tabular}{lll}
\hline & $\begin{array}{l}\text { Number of } \\
\text { interviews }\end{array}$ & $\begin{array}{l}\text { Number of } \\
\text { informants }\end{array}$ \\
\hline Local authorities & 19 & 23 \\
Voluntary organisations & 24 & 32 \\
Total & 43 & 55 \\
\hline
\end{tabular}

social welfare board, one opposing politician, the civil servant responsible for the development of support for relatives, and the manager of social services or equivalent. Additional interviews were conducted with district nurses, one project leader for the befriending service and one adviser for people with disabilities.

Furthermore, representatives of the following organisations were interviewed in each municipality: the Red Cross, parishes within the Swedish Church, the Swedish National Pensioners' Organisation (Pensionärernas Riksorganisation) and the Swedish Association for Senior Citizens (Sveriges Pensionärsförbund). Representatives of the Dementia Association were interviewed in the three municipalities in which it was present, and further organisations were interviewed if they had been mentioned as being engaged in supporting relatives.

\section{Interview structure}

The interviews were semistructured, with topics deriving from previous research and the results of a previous study (Dahlberg 2003, 2004). The interviewees were asked about: (1) their views on responsibilities of voluntary organisations and local authorities for supporting relatives of older people; (2) their views on the role of voluntary organisations; (3) their perceptions on assumed responsibility; and (4) their thoughts about future responsibilities regarding support for relatives.

\section{Procedure}

The interviews were carried out in as neutral a setting as possible or in a location chosen by the interviewee. For practical reasons, seven of the interviews were carried out via telephone. Before each interview started, information was given on the context of the study, and the interviewees were told that participation was voluntary, that they had the right not to answer specific questions, that they had the right to withdraw from the interview at any time and that their answers would be kept anonymous. They were also asked if they minded if the interview was recorded. 


\section{Data analysis}

All the interviews were recorded, transcribed in full and analysed according to the 'Framework' qualitative data analysis method (see Ritchie \& Spencer 1994), which includes several steps. To put it simply, the researcher identifies key issues, concepts and themes, according to which the data is examined. A chart is created for each theme and gives an overview of both what all respondents have said about certain aspects of a theme and what each respondent has said about the theme as a whole.

\section{Results}

The following main themes emerged from the interviews: (1) a primary local authority responsibility; (2) a complementary role of voluntary organisations; (3) the importance of collaboration between local authorities and voluntary organisations; and (4) a potentially greater role of voluntary organisations in the future.

\section{Local authority responsibility}

Interviewees representing both local authorities and voluntary organisations argued that local authorities had the main responsibility for supporting relatives. Sometimes interviewees referred to the Social Service Act and to the rights of citizens, and sometimes the local authority responsibility was merely seen as 'selfevident'. The statement 'If relatives did not care, who would?' was put forward as a motive for the local authority to support relatives as well as an obligation to do so. For example, a voluntary organisation representative said:

The final responsibility should be taken by the local authority. They are the ones who pursue it. [ ... ] I think it would be a misery if our local authority and the social services were not the ones to take responsibility for citizens.

Nevertheless, this dominant belief in local authority responsibility was not all-inclusive. There were some exceptions to and variations in this opinion, even if statutory bodies usually were identified as responsible. Some interviewees - both representing voluntary organisations and local authorities - mentioned several public authorities as responsible, i.e. local authorities together with county councils and/or the central state.

Other interviewees acknowledged the efforts of other actors and saw them as, at least in part, responsible for supporting relatives. For example, one interviewee pointed out the responsibility of relatives to make family carers ask for support in the first place. Since it is regarded as psychologically difficult for carers to ask for support, it was argued that both families and the home help service were responsible for encouraging carers to take initiatives.

In general, voluntary organisations were not seen as responsible for supporting relatives. However, one interviewee thought that local authorities could delegate tasks to voluntary organisations. The important matter was that local authorities were guaranteeing the functioning of the system and had overall control. A voluntary organisation representative compared this responsibility with 'some kind of contract between state and citizens', where people should have decent conditions even in difficult situations. However, this interviewee added that the line between the responsibility of the state and the citizens themselves was sometimes unclear, and that this was a political issue dependent upon societal norms.

The general opinion amongst voluntary organisation representatives was that they did not want to take on any responsibility. Some of them were worried about the tendency of local authorities to try to shift tasks and costs in the direction of voluntary organisations in times of strained finances. One voluntary organisation representative said:

I think that this is wrong, but I guess they take their chances. It costs a lot of money with all the services they should provide. And if others run services, the local authority is happy, because then they do not have to fund it. I think that they let go of more and more.

The preferred local authority responsibility was in line with actual, assumed responsibility, as shown in previous research (Dahlberg 2003), and with how interviewees understood the situation. Although they found it difficult to estimate how much of the support activities were provided by voluntary organisations and local authorities, respectively, it was clear that they believed local authorities did the 'great, heavy efforts', such as care tasks, relief services and rehabilitation. One voluntary organisation representative said:

The local authority stands for almost all of it. I was going to say that perhaps voluntary organisations are more the icing on the cake.

Still, interviewees thought that voluntary organisations made considerable contributions to support for relatives and that statutory support was more acknowledged. Voluntary support for relatives was often integrated with other activities, and thereby, not obvious and visible - or as one of the interviewees said: 'There are thus hidden brotherly acts.' One interviewee representing a local authority said: 'I am convinced that if counting in social contacts, voluntary organisations stand for a good deal.' 


\section{Complementary roles of voluntary organisations}

Considering the dominant opinion that local authorities were responsible for the support of relatives, one might ask what was seen to be the role of voluntary organisations. Interviewees commonly declared that voluntary organisations could help and support local authorities. In doing so, the contributions of voluntary organisations were subordinated and they were repeatedly described as complements to local authorities. For example, one politician said:

I think that it is primarily a local authority matter to make sure that this works. I mean people have paid taxes all their lives and then to be forced to find voluntary services one or the other way when you are old - I do not think that should be the starting point. Instead the core is that it is a responsibility and obligation of the local authority. But, as a complement, it is excellent with voluntary contributions.

What does it mean for an organisation to have a complementary role? What tasks do the interviewees include in this role? Representatives of voluntary organisations drew a line between care tasks and social tasks, where the former were seen as a local authority responsibility. Similarly, local authority interviewees emphasised that there must be a clear boundary between voluntary and statutory services. Interviewees stated that voluntary organisations should not be involved in caring for older people, lifting them, or giving them showers, or in tasks such as cleaning and doing the laundry.

Thus, the preferred role of voluntary organisations had to do with providing social support, a sense of belonging and social networks. Sharing experiences, arranging support groups, befriending services and leisure activities were mentioned as suitable tasks, and sometimes this was regarded as preventive of increased frailty. These activities could include relieving relatives from their caregiving role, but more in terms of providing social support and helping with practical tasks around the house than performing care tasks.

In general, voluntary organisations were prepared to give social and emotional support, and to arrange activities such as bridge, boules and study circles. They were willing to arrange dinner parties, make coffee and bake cakes. Through different forms of social interaction, they were also willing to work to reduce isolation and carry out tasks which fellow citizens can be expected to do. In addition to this, interviewees thought that voluntary organisations could play a role as organisers of befriending and relief services specifically for relatives.

However, some interviewees representing voluntary organisations thought that these kinds of tasks would be too demanding. One of the interviewees said that, if they were requested by the local authorities to take older people for walks, they would turn down the request - it would be like 'a blind man leading a blind man'. Still, in general, the limits were drawn when it came to tasks that traditionally were carried out by local authority staff, and sometimes the role of voluntary organisations was described as providing older people and relatives with services and activities on top of the basic services of local authorities:

That is to meet needs that the local authority normally might not meet, or that are peripheral to them. [ ... ] The resources of local authorities are not large enough.

In this respect, the conditions seem to be set by local authorities. This was not the case though. The interviewee quoted above was asked if he minded that his organisation should cover local authority cutbacks. He answered:

That depends. My idea is that we can never take on any formal responsibility, that the local authority contract out and use our association as a kind of subcontractor with service responsibility. I mean that, if the local authority cannot manage tasks described by law, they cannot just leave the responsibility to a voluntary organisation. However, maybe we can sometimes carry out easier things such as escort services.

Even interviewees who regarded voluntary tasks as delegated by the local authority argued that these were adapted to the abilities of voluntary organisations. One voluntary organisation representative said that voluntary organisations get the role that local authorities give them and tasks which they can accomplish - not to take over care or run a kitchen in a residential home, but to be a fellow citizen. In the end, the conditions under which voluntary organisations work are the basis of their contributions:

We will take part [in supporting relatives] to the extent that we have knowledge, interest, time and energy, but the primary responsibility always has to be the local authority's, absolutely.

Other kinds of tasks mentioned as suitable for voluntary organisations were disseminating information and advocating the rights of citizens. For instance, one voluntary organisation interviewee said that they could bridge potential gaps between relatives and local authority administrators by explaining the management of cases and applications regarding care and support, and by questioning this management. Local authority interviewees acknowledged that voluntary organisations were important 'sounding boards' for local authorities and some interviewees pointed out that voluntary organisations had a function in lobbying - or as a local authority interviewee expressed it:

They channel views that they notice, that we might not notice. Yes, at least they mediate the opinion of citizens.

Although some of those interviewed thought that voluntary organisations could take over the responsibility 
of local authorities for relief services and less-demanding home help services, in general the local authority interviewees agreed with the representatives of voluntary organisations that volunteers should not take over primary health care or local authority care of older people. Instead, interviewees pointed out that voluntary activities and services have to be flexible, and vary from one area and time to another, i.e. that there is a truly voluntary basis. Furthermore, some interviewees expressed a concern over becoming too dependent upon voluntary efforts:

But we must not just rely on voluntary work. We must know where to draw the line. [ ... ] It is easy to see that voluntary work has to take over more and more, and I do not think they are capable of that. In order not to become compulsory, it should be organised on a voluntary basis and include only such tasks that both parties want them to carry out.

\section{Collaboration}

Besides being complementary to local authorities, interviewees argued that voluntary organisations could be their collaborators by contributing with a different perspective on both support services and the situation of relatives. Through their channels and networks, they could also reach people who local authorities may not have any contact with. Furthermore, interviewees pointed out that 'all good forces' needed to contribute and that local authorities were grateful for all the help they were given:

The background is a kind of political insight: 'We cannot manage this by ourselves in the long run. Instead we have to be several actors, and then it is good if we can cooperate with the voluntary organisations.'

It was said that local authorities could encourage voluntary organisations, but if the managing civil servant was not interested in cooperation, voluntary organisations would be cut out. Moreover, collaboration could also lead to an increased responsibility. A voluntary organisation representative argued that greater involvement of voluntary organisations in supporting relatives could mean that the organisations would start to feel responsible for this.

\section{Potentially greater responsibility for voluntary organisations in the future}

Both interviewees representing voluntary organisations and those representing local authorities pointed out the increasing need of support for relatives as a result of the growing number of older people in the population. According to interviewees, this increased need can hardly be met by local authorities alone.
Local authority representatives stated that voluntary contributions need to be stimulated and acknowledged, and a voluntary organisation representative said that the current state-stimulated development was one way of trying to involve voluntary organisations in supporting relatives. However, growth in voluntary activity might be hindered by difficulties in recruiting people to carry out voluntary work. Therefore, as one local authority interviewee said, local authorities have to carry the development and the inclusion of voluntary organisations: 'They [voluntary organisations] are hardly capable of carrying themselves.' In other words, this interviewee thought that the development of voluntary contributions was in the hands of local authorities.

One of the voluntary organisation representatives said that there were 'risks that more and more [services] will be transferred to voluntary organisations', and another said that the current welfare mix was appropriate since more expectations should not be placed on pensioners. One of the politicians said that nobody could demand anything from voluntary organisations. She argued that they have to contribute on their own terms and should not feel obliged to carry out voluntary work. A voluntary organisation representative stated:

It is meant to become better and better in society, and that the public [sector] should help us. Then one should not rely on voluntary efforts. I think that that is really wrong on the whole. It should not be necessary. I hope that it [the voluntary services] does not increase.

Still, other interviewees hoped that voluntary contributions would increase, and some of them thought that this might even be necessary. Some interviewees representing voluntary organisations wanted a mixed supply of welfare and were willing to contribute to this. However, even those who were positive towards voluntary contributions believed in an indispensable responsibility of local authorities. In general, they did not support the idea of having to rely on voluntary efforts. A voluntary organisation interviewee summarized:

We are a necessary complement to the Swedish [public] society of today. So it must not be that we start to take on a responsibility that society, strictly speaking, should have, that we take over.

\section{Discussion}

Representatives of both local authorities and voluntary organisations identified local authorities as responsible for supporting relatives, which is in accordance with the recommendations of the Swedish Social Service Act. They also thought that voluntary activities were and should be complementary to activities arranged by local authorities, and in general, voluntary organisations 
had no wish to fill in where the state had failed - contrary to what has been suggested by, for example, the Swedish National Board of Health and Welfare (Socialstyrelsen 2002b).

Support for the idea of complementary roles for voluntary organisations is not unique to the area of support for relatives of older people. In other policy areas, Johansson (2002) found that many local authority representatives see voluntary organisations as complementary to local authorities and as having become more significant in this role. Furthermore, these representatives believe that voluntary organisations will become increasingly complementary to local authorities in the future.

The idea of complementarity is also evident in Swedish political debate. In fact, the term 'complementary' is used almost as a mantra in describing the role of voluntary organisations in the Swedish welfare system. For example, the director of the Swedish National Board of Health and Welfare has argued that the voluntary sector should be an alternative and a complement to statutory service providers (Socialstyrelsen 2003); the minister for public health and social services has said that the role of voluntary organisations is to 'reinforce and complement' (Socialstyrelsen 2003, p. 22, my translation) the public sector and to mould public opinion; and in a parliamentary debate, politicians from both the left and the right identified the role of voluntary organisations as complementary (Sveriges Riksdag 1998). An example from the Swedish media is an article in Dagens Nyheter (Johansson 2003) in which three different individuals use the term 'complementary' in describing the role of voluntary organisations in relation to the state.

In the present study, interviewees specified in what way voluntary organisations could be complementary to local authorities. They argued that voluntary organisations were suitable for less-demanding tasks and social support (cf. Faulkner \& Davies 2005). Hoad (2002) identified a similar discussion on the boundary between tasks performed by volunteers, and work that requires the special skills and knowledge of professionals. This finding might seem to fit complementarity theory's 'principle of matching' (Litwak 1985). However, the actual service provision shows that some voluntary organisations take on a great responsibility, and that local authorities and voluntary organisations can provide the same kind of services (Dahlberg 2003, Jegermalm 2003). Therefore, how is it that there is complementarity between voluntary and statutory activity locally at the same time as structural elements of complementarity theory are challenged?

The strong ideological support for the idea of complementarity between local authorities and voluntary organisations is likely to be the key to understanding complementarity. This idea or norm is expressed by interviewees who are active in social policy and voluntary organisations, and it finds support in media and political debate. Consequently, it will influence their wish to arrange services, the social policy and the actual service provision at a local level.

The complementarity norm is linked to what has been discussed elsewhere in terms of a 'pro-State tradition' (Lundström \& Svedberg 2003, p. 223) and 'statefriendliness' (Rothstein 2002, p. 299). In Norway and Sweden, voluntary organisations have been forceful in making the state take on a greater responsibility (Kuhnle \& Selle 1992, Rothstein 2002), and there is a great degree of cooperation between voluntary organisations and the state (Kuhnle \& Selle 1992, Dahlberg 2003). Nevertheless, it is important to note that there has been a substantial increase in service provision by private companies since the 1990s (Blomqvist 2004, Engström 2004), and a greater political interest in and acknowledgement of service provision by voluntary organisations (e.g. Jeppsson-Grassman 2005).

However, there are substantial variations across Western countries in both attitudes towards the welfare state (Svallfors 2003, 2004) and in coverage of care for older people (Blackman 2000, Bettio \& Plantenga 2004). The welfare state has particularly strong support in Sweden and Norway (Svallfors 2003). Research shows that $60-70 \%$ of older people in Sweden prefer to receive help from the public sector (Andersson \& Johansson 1996, Szebehely 1998), while there is less support for a governmental responsibility 'to provide a decent standard of living for the old' in Germany, New Zeeland, Australia, Canada and the USA (Svallfors 2003, p. 505).

It is likely that there are parallel variations regarding preferred roles of voluntary organisations. For example, the liberal welfare regime of the UK has a lower level of government social welfare spending and a relatively large non-profit sector (Anheier \& Salamon 2001), and there are high and increasing expectations on voluntary organisations to contribute to welfare provision. Recently, HM Treasury published a cross-cutting review of the role of the voluntary and community sector in service delivery (HM Treasury 2002) in which this sector is identified as a key partner in delivering government policies. Following this review, major governmental investments have been made to increase the capacity and sustainability of the voluntary and community sector in the UK (see HM Treasury 2005).

When only looking at interaction between different service providers from a structural perspective and at an aggregated level, there is a risk that what is going on locally is overseen and complementarity might not seem to be the case. There is also a tendency to regard voluntary organisations as shaped by public policies (cf. 
Wijkström \& Lundström 2002). The main focus within complementarity theory is placed on characteristics of the actors and their suitability of carrying out certain tasks. This needs to be combined with studies of the actors' opinions and views. Pfau-Effinger (2005) argued that ideas of social actors are essential in policy-making since policies are embedded in cultural values and models such as the welfare mix, and the relationship between the state and other actors, while Bettio \& Plantenga (2004, p. 85) claimed that ideals about care are 'at the core of individual national identities'.

The present author has argued that norms and ideals do not only influence policy-making and how services are talked about, but also influence people's wish to be involved in voluntary work and the outcome in terms of welfare provision. Therefore, rather than primarily focusing on the characteristics of the actors, it is essential to examine their views on the preferred role of voluntary organisations and the state. For example, one might ask whether the complementarity norm is more dominant in social-democratic than in liberal or corporatist welfare regimes. One might also ask to what extent expectations placed on voluntary organisations to contribute to service provision are influenced by the availability of private service provision. As shown in the present article, studies of this kind can contribute to an understanding of the nature of service provision; for example, the reason why it is complementary at a local level even though there are overlaps nationally.

\section{Acknowledgements}

This study was funded by the Swedish National Board for Health and Welfare, together with 15 local authorities in Dalarna and the Dalarna County Council, Sweden. For comments on drafts of this paper, I am grateful to Kevin McKee, Sheffield Institute for Studies on Ageing, Sheffield University, Sheffield, UK.

\section{References}

Amnå E. (1995) Det mångtydiga mellanrummet. Några utländska forskningsimpulser. [The ambiguous place between. Some international research ideas.] In: E. Amnå (Ed.) Medmänsklighet att hyra [Human Kindness for Hire], pp. 119-171. Libris, Orebro.

Andersson L. \& Johansson L. (1996) Äldres behov av och inställning till hjälp och vård. [Older people's need of and view on help and care.] In: L. Johansson (Ed.) Äldres hälsa, behov och bruk av service och vaird [Older People's Health, Need and Usage of Social and Health Services], pp. 89-103. Socialstyrelsen, Stockholm.

Anheier H.K. \& Salamon L.M. (2001) Volunteering in a CrossNational Perspective: Initial Comparisons. Centre for Civil Society, London School of Economics and Political Science, London.
Arts W. \& Gelissen J. (2002) Three worlds of welfare capitalism or more? A state-of-the-art report. Journal of European Social Policy 12 (2), 137-158.

Attias-Donfut C. (2001) The dynamics of elderly support. The transmission of solidarity patterns between generations. Zeitschrift für Gerontologie und Geriatrie 34 (1), 9-15.

Bettio F. \& Plantenga J. (2004) Comparing care regimes in Europe. Feminist Economics 10 (1), 85-113.

Blackman T. (2000) Defining responsibility for care: approaches to the care of older people in six European countries. International Journal of Social Welfare 9 (3), 181-190.

Blomqvist P. (2004) The choice revolution: privatization of Swedish welfare services in the 1990s. Social Policy and Administration 38 (2), 139-155.

Chappell N. \& Blandford A. (1991) Informal and formal care: Exploring the complementarity. Ageing and Society 11, 299-317.

Daatland S.O. (1990) What are families for? On family solidarity and preference for help. Ageing and Society 10, 1-15.

Daatland S.O. \& Herlofson K. (2001) Service systems and family care - substitution or complementarity? In: S.O. Daatland \& K. Herlofson (Eds) Ageing, Intergenerational Relations, Care Systems and Quality of Life - An Introduction to the OASIS Project. NOVA, Oslo.

Dahlberg L. (2003) Voluntary organisations in a strong welfare state: a study of support for relatives of older people in Sweden. Generations Review 13 (4), 4-8.

Dahlberg L. (2004) Substitution in statutory and voluntary support for relatives of older people. International Journal of Social Welfare 13 (2), 181-188.

Dahlberg L. (2005) Interaction between voluntary and statutory service provision: a matter of welfare pluralism, substitution or complementarity? Social Policy and Administration 39 (7), 740-763.

Engström B. (2004) Konkurrensutsättning och entreprenader inom äldreomsorgen Utvecklingsläget 2003. Socialstyrelsen, Stockholm.

Esping-Andersen G. (1990) The Three Worlds of Welfare Capitalism. Polity Press, Cambridge.

Esping-Andersen G. (2002) Towards the good society, once again? In: G. Esping-Andersen (Ed.) Why We Need a New Welfare State, pp. 1-25. Oxford University Press, Oxford.

European Commission (2004) The Social Situation in the European Union 2004. [WWW document.] URL http:// europa.eu.int/comm/employment_social/publications/2004/ keag04001_en.pdf

Faulkner M. \& Davies S. (2005) Social support in the healthcare setting: the role of volunteers. Health Social Care in the Community 13 (1), 38-45.

Giddens A. (1998) The Third Way: The Renewal of Social Democracy. Polity Press, Cambridge.

Henriksen L.S. \& Bundesen P. (2004) The moving frontier in Denmark: voluntary-state relationships since 1850. Journal of Social Policy 33 (4), 605-625.

HM Treasury (2002) The Role of the Voluntary and Community Sector in Service Delivery: A Cross Cutting Review. [WWW document.] URL http://www.hm-treasury.gov.uk/media/ 890/03/CCRVolSec02.pdf

HM Treasury (2005) Exploring the Role of the Third Sector in Public Service Delivery and Reform: A Discussion Document. [WWW document.] URL http://www.hm-treasury.gov.uk/media/ 34C/1D/vcs_thirdsector210205.pdf

Hoad P. (2002) Drawing the line: the boundaries of volunteering in the community care of older people. Health Social Care in the Community 10 (4), 239-246. 
Jegermalm M. (2003) Support for carers of older people: the roles of the public and voluntary sectors in Sweden. Social Policy and Administration 37 (7), 756-771.

Jeppsson-Grassman (2005) På jakt efter den frivilliga sektorns roll inom nordisk äldreomsorg. Forskning, gestaltningar och perspektiv. [Searching for the role of the voluntary sector in Nordic elder care: research, interpretations and perspectives.] In: M. Szebehely (Ed.) Äldreomsorgsforskning $i$ Norden: En kunskapsöversikt [Research on Elder Care in the Nordic Countries: A Research Overview], pp. 281-320. Nordic Council of Ministers, Copenhagen.

Johansson S. (2002) Sociala ideella organisationer - som kommunerna ser dem. Om kommunernas relationer med sociala ideella organisationer. [Independent Movements or Statutory Suppliers. The Role of Voluntary Organisations in the Welfare System.] Socialstyrelsen, Stockholm.

Johansson L. (2003) När samhället inte räcker till. [When the society is not enough.] Dagens Nyheter 15 November.

Kinsella K. \& Velkoff V.A. (2002) The demographics of aging. Aging Clinical and Experimental Research 14 (3), 159-169.

Kuhnle S. \& Alestalo M. (2000) Growth, adjustments and survival of European welfare states. In: S. Kuhnle (ed.) Survival of the European Welfare State, pp. 4-18. Routledge, London.

Kuhnle S. \& Selle P. (1992) Government and voluntary organizations: a relational perspective. In: S. Kuhnle \& P. Selle (Eds) Government and Voluntary Organizations: A Relational Perspective, pp. 1-33. Avebury, Aldershot.

Lingsom S. (1997) The Substitution Issue. Care Policies and Their Consequences for Family Care. NOVA, Oslo.

Litwak E. (1985) Helping the Elderly: The Complementary Roles of Informal Networks and Formal Systems. Guilford Press, New York, NY.

Lundström T. \& Svedberg S. (2003) The voluntary sector in a social democratic welfare state - the case of Sweden. Journal of Social Policy 32 (2), 217-238.

Lyons K.S. \& Zarit S.H. (1999) Formal and informal support: the great divide. International Journal of Geriatric Psychiatry 14 (3), 183-196.

Lyons K.S., Zarit S.H. \& Townsend A.L. (2000) Families and formal service usage: stability and change in patterns of interface. Aging and Mental Health 4 (3), 234-243.

Penning M.J. (2002) Hydra revisited: substituting formal for self- and informal in-home care among older adults with disabilities. The Gerontologist 42 (1), 4-16.

Pfau-Effinger B. (2005) Culture and welfare state policies: reflections on a complex interrelation. Journal of Social Policy 34 (1), 3-20.

Philp I. (Ed.) (2001) Family Care of Older People in Europe. IOS Press, Amsterdam.

Ritchie J. \& Spencer L. (1994) Qualitative data analysis for applied policy research. In: A. Bryman \& R.G. Burgess (Eds) Analyzing Qualitative Data. Routledge, London.

Rothstein B. (2002) Sweden. Social capital in the social demo- cratic state. In: R.D. Putnam (Ed.) Democracies in Flux. The Evolution of Social Capital in Contemporary Society, pp. 289-331. Oxford University Press, New York.

Schneider J., Hallam A., Islam K.M., et al. (2003) Formal and informal care for people with dementia: variations in cost over time. Ageing and Society 23 (3), 303-326.

Socialstyrelsen [Swedish National Board for Health and Welfare] (2002a) Anhörig 300 - slutrapport. [Relatives 300: Final Report.] Socialstyrelsen, Stockholm.

Socialstyrelsen [Swedish National Board for Health and Welfare] (2002b) Vart bär det hän-är det frivilligt? [Where Are We Heading - Is it Voluntary?] Socialstyrelsen, Stockholm.

Socialstyrelsen [Swedish National Board for Health and Welfare] (2003) Statens' bästa vän? Den ideella sektorns roll i ett internationellt och svenskt perspektiv. [The State's Best Friend? The Role of the Voluntary Sector in an International and Swedish Perspective.] Socialstyrelsen, Stockholm.

Svallfors S. (2003) Welfare regimes and welfare opinions: a comparison of eight Western countries. Social Indicators Research 64 (3), 495-520.

Svallfors S. (2004) Class, attitudes and the welfare state: Sweden in comparative perspective. Social Policy and Administration 38 (2), 119-138.

Sveriges Riksdag (1998) Parliamentary Debate Protocol 1997/98:120, June 8, 1998. [WWW document.] URL http://rixlex.riksdagen.se/htbin/thw/1993/http://rixlex.riksdagen.se?\$BASE\} $=$ PROTARKIV9798\& $\$\{$ THWIDS $\}=0.58] 10733866181069 \& \$$ $\{$ HTML $\}=$ PROT DOK\&\$THWURLSAVE $\}=58] 10733866181069$

Szebehely M. (1998) Hjälp i hemmet i nedskärningstid hemtjänstens och anhörigas insatser för gamla kvinnor och män. [Home help in times of cutbacks - contributions for older women and men by the home help service and relatives.] In: A.M. Sandquist (Ed.) Åt Var Och En Efter Behov [To Each According to Needs], pp. 93-179. Svenska Kommunförbundet, Stockholm.

Szebehely M. (2005) Äldreomsorger i Norden - verksamheter, forskning och statistik. [Elder care in the Nordic countries: services, research and statistics.] In: M. Szebehely (Ed.) Äldreomsorgsforskning $i$ Norden: En kunskapsöversikt [Research on Elder Care in the Nordic Countries: A Research Overview], pp. 21-51. Nordiska Ministerrådet, Köpenhamn.

Thoraeus Olsson O. (1990) Efter 80 en undersökning om äldre människors sociala omsorgsbehov och deras omsorgssituation. [After Eighty: A Study of Older People's Requirements for Social Care, and of Their Care Situations.] Socialhögskolan, Stockholms universitet, Stockholm.

Wijkström F. \& Lundström T. (2002) Den ideella sektorn organisationerna i det civila samhället. [The Voluntary Sector Organisations in the Civil Society.] Sober Förlag, Stockholm.

Winqvist M. (1999) Vuxna barn med hjälpbehövande föräldrar - en livsformsanalys. [Adult Children of Parents in Need of Assistance: A Life-Mode Analysis.] Sociologiska institutionen, Uppsala universitet, Uppsala. 